\title{
Effects of 24 Years of Conservation Tillage Systems on Soil Organic Carbon and Soil Productivity
}

\author{
Kenneth R. Olson, ${ }^{1}$ Stephen A. Ebelhar, ${ }^{2}$ and James M. Lang ${ }^{3}$ \\ ${ }^{1}$ Department of Natural Resources and Environmental Sciences, University of Illinois, S-224 Turner Hall, \\ 1102 S. Goodwin Avenue Urbana, IL 61801, USA \\ ${ }^{2}$ Dixon Springs Agricultural Center, Department of Crop Sciences, Simpson, IL 62959, USA \\ ${ }^{3}$ Department of NRES, University of Illinois, N-405 Turner Hall, 1102 S. Goodwin Avenue, Urbana, IL 61801, USA \\ Correspondence should be addressed to Kenneth R. Olson; krolson@illinois.edu
}

Received 6 December 2012; Revised 15 January 2013; Accepted 17 January 2013

Academic Editor: Philip J. White

Copyright (C) 2013 Kenneth R. Olson et al. This is an open access article distributed under the Creative Commons Attribution License, which permits unrestricted use, distribution, and reproduction in any medium, provided the original work is properly cited.

\begin{abstract}
The 24-year study was conducted in southern Illinois (USA) on land similar to that being removed from Conservation Reserve Program (CRP) to evaluate the effects of conservation tillage systems on: (1) amount and rates of soil organic carbon (SOC) storage and retention, (2) the long-term corn and soybean yields, and (3) maintenance and restoration of soil productivity of previously eroded soils. The no-till (NT) plots did store and retain $7.8 \mathrm{Mg} \mathrm{Cha}^{-1}$ more and chisel plow (CP) $-1.6 \mathrm{MgCha}^{-1}$ less SOC in the soil than moldboard plow (MP) during the 24 years. However, no SOC sequestration occurred in the sloping and eroding NT, CP, and MP plots since the SOC level of the plot area was greater at the start of the experiment than at the end. The NT plots actually lost a total of $-1.2 \mathrm{MgCha}^{-1}$, the CP lost $-9.9 \mathrm{MgCha}^{-1}$, and the MP lost $-8.2 \mathrm{MgCha}^{-1}$ during the 24-year study. The long-term productivity of NT compared favorably with that of MP and CP systems.
\end{abstract}

\section{Introduction}

Conservation program was established to take highly erodible lands out of production. In the United States, the Food Security Act of 1985, the 1990, 1995, 2001, 2006, and 2011 Farm bills, and the Illinois T by 2000 Program have resulted in millions of hectares of erodible land previously in row crops being put into the CRP for 15 to 25 years. Any conversion of Conservation Reserve Program (CRP) land back to corn and soybean production could require the use of conservation tillage systems such as NT to meet soil erosion control standards. Evaluations of yield response of these conservation tillage systems over time are needed to assess returning this land to crop production, the effects on SOC storage and retention and crop yields.

Conservation tillage (defined as having $30 \%$ residue at the time of planting) can result in an increase in crop yield when compared with that of a moldboard plow system. Lawrence et al. [1] showed in a 4-year study in a semiarid environment in Australia that no-till had a higher crop yield than did reduced till fallow or conventional till fallow. Wilhelm et al. [2] observed a positive linear response between yields of corn and soybean, and amount of residue applied to a notill system. Lueschen et al. [3], in a corn-soybean rotation in Minnesota, found an increase of $6.30 \mathrm{Mg} \mathrm{ha}^{-1}$ in yield of the NT system above the MP system in a dry year. Kapusta et al. [4] studied the effects of tillage systems for 20 years and found equal corn yield for no-till, reduced till, and conventional tillage systems despite the lower plant population in no-till.

Maintaining crop residue on the soil surface $[5,6]$ can reduce the severity of erosion. At planting with chisel plowing, residue cover has to be 30 percent or more, but often much higher with no-till (usually $50 \%$ or more residue) due to minimum soil disturbance [7]. Lueschen et al. [3], for a corn-soybean rotation in Minnesota, observed 69 to 82, 49, and 10 percent of soybean residue cover on the soil surface after corn planting in no-tillage, chisel plow, and moldboard plow system plots, respectively.

The impact of tillage and cover crops on SOC sequestration (net increase) or loss has been the focus of many studies 
since this management techniques are thought to contribute to atmospheric $\mathrm{C}$ loss or sequestration. SOC sequestration or retention has been shown to retain more SOC with decreasing disturbance or enhanced rotation diversity [8]. Many of the early studies found NT to have significantly higher SOC than MP and CP systems when the soils were only sampled to 15 or $30 \mathrm{~cm}$ depth $[8,9]$. The NT plots have SOC concentrated in the top $30 \mathrm{~cm}$, but was dispersed to greater depths in tilled plots $[9,10]$.

Decline of SOC content in agricultural systems and increased awareness of its importance to global $\mathrm{C}$ budgets has accelerated evaluations of land management impacts on soil C dynamics and storage [11]. Land use practices that may affect SOC sequestration include a switch to NT [12]. The impact of tillage on SOC sequestration (net increase) or loss has been the focus of many studies since these management techniques contribute to atmospheric $\mathrm{C}$ loss or sequestration. SOC sequestration or retention has been shown to occur with decreasing soil disturbance or enhanced crop rotation diversity.

Change in frequency and intensity of tillage practices alter the bulk density and soil organic matter in the soil profile. Mann [13] reported that the reduction in SOC content of soils having an initial content of between 20 and $50 \mathrm{~g} \mathrm{~kg}^{-1}$ was 20 percent less after cultivation. He found that changes in SOC content were most pronounced during the first 20 years of cultivation. Also, changes in SOC storage were more variable in the upper $15 \mathrm{~cm}$ of soil than in the upper $30 \mathrm{~cm}$. Varvel and Wilhelm [14] studied the use of conservation tillage systems for corn and soybean production and found soil organic carbon levels were maintained or even increased in all tillage system with the greatest increase obtained in systems with the least amount of soil disturbance which strongly support the adoption and use of conservation tillage systems for soil sustainability.

Franzluebbers and Follett [15] reported that SOC content of timberland and prairie soils declined with cultivation in North America. The rate of decline as a result of cultivation was $22 \% \pm 10 \%$ for the northeast; no value was reported for the central, $25 \% \pm 33 \%$ for southwest, and $36 \% \pm 29 \%$ for southeast. Ismail et al. [16] observed a decrease in SOC in the 0 - to $30-\mathrm{cm}$ silt loam layer of soil during the first 5 years, no change in the next 5 years, and an increase in SOC in the last 10 years in both NT and MP in comparison with sod plots. SOC was higher in NT than in MP. Hunt et al. [17] and Angers and Giroux [18] found NT systems increased SOC content, compared with MP and CP systems, in the top 5-cm layer of soils with a range of soil textures, including loamy sand, silt loam, and silty clay loam.

Mulvaney et al. [19] did not find an increase in soil organic matter build-up in response to increased crop residue input as a result of fertilizer $\mathrm{N}$ applications when a pretreatment SOC data were collected and used as the baseline to determine SOC change over time in long-term cereal cropping experiments. Khan et al. [20] found that the use of the comparison method with SOC content measurements only taken in the middle and at the end of a variable rate $\mathrm{N}$ fertilizer, crop yield, and SOC sequestration studies resulted in an overestimation of the magnitude and rate of SOC sequestration in response to $\mathrm{N}$ fertilizer. Comparison studies with one treatment as the baseline or control should not be used to determine SOC sequestration, if soil samples are only collected and tested once during or at the end of study. Only experimental designs with pretreatment SOC measurements (baseline data) made before or at the start of long-term field studies should be used.

Olson [21] found that the SOC content of the MP treatment, used as baseline in comparison method studies, was not at steady state during the $20 \mathrm{yr}$ tillage experiment at Dixon Springs, Illinois. In fact MP plots lost $-15.2 \mathrm{Mg} \mathrm{C} \mathrm{ha}^{-1}$ from the root zone as a result of mixing, intensity of crop rotation, aeration, and eroded SOC rich sediments being transported off the plot area [22]. NT treatment only reduced the magnitude and rate of SOC loss over time. The pair comparison method used by many researchers with MP as baseline suggested $+9.1 \mathrm{MgCha}^{-1}$ of SOC sequestration occurred during the $20 \mathrm{yr}$ experiment [21]. However, the 1988 pretreatment baseline method did not validate the SOC sequestration value. At this site the sloping and eroding NT plot actually lost $-6.8 \mathrm{MgC} \mathrm{ha}^{-1}$ during the 20 -year study so no actually SOC sequestration occurred. The assumption that the MP was at a steady state, made by researchers $[15,23-27]$ using the comparison method with one year of SOC sampling near the end, was incorrect and resulted in an SOC sequestration finding that was invalid. Olson [21] findings suggest a pretreatment SOC baseline is essential in all tillage comparison studies to determine the amount and rate of SOC sequestration, steady state, or loss. A pretreatment SOC baseline was needed in these comparison studies when determining the amount and rate of SOC sequestration, storage, retention, or loss, especially on sloping and eroding soils with more intensive cropping rotations (more row crops and fewer years of forages) during the study than in previous years.

Shorter term tillage studies [28-30] were extended to 24 years with the objective of evaluating long-term tillage systems (NT, CP, and MP) effects on corn and soybean yields and the effects on the SOC storage or retention and the maintenance and restoration of soil productivity of previously eroded soils in southern Illinois. These SOC storage and retention values by tillage treatment at the end of the study will be compared to pretreatment SOC levels to determine the amount and rate of SOC sequestration or loss as a result of the 24 years of tillage treatments. The study was extended to show that NT system can be used instead of MP or CP systems to reduce soil erosion and maintain long-term crop yields.

\section{Materials and Methods}

A conservation tillage experiment was started in 1989 at the Dixon Springs Agricultural Research Center in southern Illinois. The soil at the study site was a moderately eroded phase of Grantsburg silt loam (fine-silty, mixed, mesic Typic Fragiudalf) [31] with an average depth of $64 \pm 6 \mathrm{~cm}$ to a rootrestricting fragipan. The area had an average slope gradient of 6 percent. Starting with corn in 1989, corn and soybean were grown in alternate years. The experimental design was two Complete Latin Squares and each square has three rows 
and three columns [32] which allowed for randomization of the tillage treatments (NT, CP, and MP) both by row (block) and by column. This replication was used to control random variability in both directions. Each tillage treatment was randomized six times in 18 plots with a size of $9 \mathrm{~m} \times 12 \mathrm{~m}$. The columns were initially separated with $6 \mathrm{~m}$ buffer strips of sod. Later the buffer strips were planted to NT corn and soybeans to reduce deer damage. An electric fence was later used to protect the crops in the plots. There was a $60 \mathrm{~m}$ wide filter strip between the plot area and the drainage way.

The implements used in each tillage system and depth of tillage were as follows: NT (John Deere No-Till planter with wavy coulters), CP (straight-shanked chisel plowed to $15 \mathrm{~cm}$ with disking to $5 \mathrm{~cm}$ ), and MP (moldboard plowed to $15 \mathrm{~cm}$ with disking to $5 \mathrm{~cm}$ ). In the spring of each year the MP and CP plots were moldboard and chisel plowed followed by 2 disking and planting. In odd years corn was planted at the seeding rate of 64,000 seeds $\mathrm{ha}^{-1}$ with fertilizers of $218 \mathrm{~kg} \mathrm{ha}^{-1} \mathrm{~N}, 55 \mathrm{~kg} \mathrm{ha}^{-1} \mathrm{P}$, and $232 \mathrm{~kg} \mathrm{ha}^{-1} \mathrm{~K}$. The tillage study did not focus on $\mathrm{N}$ fertilizer application in corn years since the rate was the same for both conventional (MP) and conservation (NT and $\mathrm{CP}$ ) tillage systems.

The percentage surface residue was determined after planting by the line-transect method [33]. Plant population for the center 0.001 ha of each plot was determined by counting at 25 days after planting. The crop yield and plant population data from 1989 to 2012 were collected as part of this study. The soil loss rates were not measured directly. They were determined using RUSLE2 [34] and USLE [35] models that have been validated and widely used in USA by USDA, NRCS Soil Conservationists.

2.1. Field and Laboratory Methods. Soil samples were collected in September of 1988 (prior to the establishment of the tillage experiment in spring of 1989), in August of 2000 and in June of 2009, at depths of 0- to 5-, 5- to 15-, 15- to 30-, 30to 45-, 45- to 60-, and 60- to 75-cm for SOC determination. The sampling depth was limited due to the presence of a root restricting fragipan at a $64 \pm 6 \mathrm{~cm}$ depth. Previous soil sampling found only trace amounts of SOC present below a $75 \mathrm{~cm}$ depth, probably from previous grass roots penetrating the fragipan along the prism faces. Four soil cores $(3.2 \mathrm{~cm}$ diameter), one from near each of the four corners of the plot $(1.5 \mathrm{~m}$ from adjacent, above or below plot, and $1.5 \mathrm{~m}$ from border strip), were obtained for each depth and composited by crumbling and mixing. The samples were air-dried and pulverized to pass through a $2 \mathrm{~mm}$ sieve prior to analysis. The SOC was determined after removal of un-decomposed plant residue using the modified acid-dichromate organic carbon procedure number 6A1 [36]. Field moist core bulk density was determined [36] using a Model 200 soil core sampler $(5.6 \mathrm{~cm}$ in diameter and $6 \mathrm{~cm}$ high) manufactured by Soil Moisture Equipment Corp.

2.2. Statistical Methods. Statistical analysis for all parameters was performed using the procedures from Statistical Analysis System (SAS) computer software [37]. Analysis of variance and least square means of crop yield and SOC content were performed by General Linear Model (GLM) procedures. Analysis of variance and least square means of crop yield and SOC content were performed by General Linear Model (GLM) procedures. An LSD procedure was used at the $P=0.05$ level to determine, if there were significant SOC differences between tillage treatments for the same date and depth.

\section{Results}

The NT system maintained a significantly greater amount of residue on the soil surface as compared with that of the $\mathrm{CP}$, and MP systems at planting during each selected year (Table 1). Crop residue on the soil surface was greater with corn as previous crop, compared with that of soybean because of greater residue production from corn and slower rate of decomposition of corn residue [38] than soybean residue. On Grantsburg soil with 5-7 percent slopes, the estimated annual soil loss, determined with USLE and RUSLE2, was 8, 20, and $30 \mathrm{Mg} \mathrm{ha}^{-1}$ with the NT, CP, and MP systems, respectively, (Table 1) [34,35]. The greater the percentage of crop residue (Table 1) on the soil surface with the NT system protected the soil from erosion keeping it below the tolerance level of $8.4 \mathrm{Mg} \mathrm{ha}^{-1} \mathrm{yr}^{-1}$ [35]. On the other hand, rill erosion was observed with the MP and CP systems as a result of fewer residues on soil surface compared with that of the NT system.

Rainfall data (30-year average growing season rainfall by month for the southeastern Illinois, USA) and 1989-2012 growing seasons are shown in Table 2. The 30-year average cumulative rainfall during April-September in southeastern Illinois was $64.4 \mathrm{~cm}$. Seven years $(1991,1994,1999,2004,2007$, 2008 , and 2012) could be characterized as dry years with a growing season rainfall of $43.3,50.7,47.7,38.3,44.4,45.8$, and $37.1 \mathrm{~cm}$, respectively.

From 1989 to 2012, the MP system had greater plant populations than the other tillage systems in 6 of 24 years (Table 3). The NT system had greater plant population than the other tillage systems in 7 of 24 years while CP only had 1 of 24 years with greater plant populations than the other tillage systems. In 1989, 1996, 1998, 2002, and 2006, the NT had fewer plants per plot (Table 3 ) compared with the other tillage systems which was probably due to insufficient soilseed contact, lower germination, and greater soil strength in the NT system [28]. During 1990, 1996, 2002, 2006, and 2011 the high April and May rainfalls (Table 2) contributed to less plants per plot with the NT system compared with that of the MP system (Table 3). Better seed-soil contact with the MP system could have increased the germination compared with that of the NT system during 1996, 2002, and 2006 (Table 3). On the other hand, in 1994 and 2000 the plant population was greater with the NT treatment compared with that of the MP treatments, which could have been due to relatively greater water availability in the NT system compared with MP tillage system at planting. Twelve-year average plant population (Table 3) for corn and soybean was not statistically different from NT and MP systems.

In 2004, one of the driest years, the soybean yields were zero for all treatments (Table 4) since all plant available 
TABLE 1: Effect of different tillage treatments on plant residue after planting and soil loss at Dixon Springs. Odd years have soybean residue and even years have corn residue.

\begin{tabular}{lccccccccccc}
\hline \multirow{2}{*}{ Tillage } & \multicolumn{4}{c}{ Residue present from previous crop (\% cover) } & \multicolumn{4}{c}{ Soil loss $^{\#}$} \\
& 1996 & 1997 & 1998 & 1999 & 2005 & 2006 & 2007 & 2011 & 2012 & $\left(\mathrm{Mg} \mathrm{ha}^{-1}\right)$ \\
\hline No-till & $91 \mathrm{a}^{*}$ & $75 \mathrm{a}$ & $95 \mathrm{a}$ & $73 \mathrm{a}$ & $85 \mathrm{a}$ & $90 \mathrm{a}$ & $78 \mathrm{a}$ & $74 \mathrm{a}$ & $88 \mathrm{a}$ & $8 \mathrm{c}$ \\
Chisel plow & $21 \mathrm{~b}$ & $18 \mathrm{~b}$ & $29 \mathrm{~b}$ & $21 \mathrm{~b}$ & $18 \mathrm{~b}$ & $28 \mathrm{~b}$ & $24 \mathrm{~b}$ & $20 \mathrm{~b}$ & $28 \mathrm{~b}$ & $20 \mathrm{~b}$ \\
Moldboard plow & $6 \mathrm{c}$ & $6 \mathrm{c}$ & $17 \mathrm{c}$ & $5 \mathrm{c}$ & $5 \mathrm{c}$ & $10 \mathrm{c}$ & $8 \mathrm{c}$ & $6 \mathrm{c}$ & $9 \mathrm{c}$ & $30 \mathrm{a}$ \\
\hline
\end{tabular}

${ }^{*}$ For each year means in a same column followed by the same letter is not significantly different at the $P=0.05$ probability level.

${ }^{\#}$ Soil loss is calculated by Universal Soil Loss Equation (USLE) and Revised Universal Soil Loss Equation (RUSLE2).

TABLE 2: Rainfall data for 1989-2012 growing season at Dixon Springs in Southern Illinois.

\begin{tabular}{|c|c|c|c|c|c|c|c|}
\hline \multirow{2}{*}{ Year } & \multicolumn{7}{|c|}{ Rainfall $(\mathrm{cm})$} \\
\hline & April & May & June & July & August & September & Growing season \\
\hline 1989 & 6.1 & 4.1 & 14.3 & 12.8 & 10.0 & 4.6 & 51.9 \\
\hline 1990 & 14.5 & 28.2 & 4.4 & 6.4 & 10.5 & 8.8 & 72.8 \\
\hline 1991 & 12.5 & 8.9 & 1.8 & 3.7 & 4.0 & 12.4 & 43.3 \\
\hline 1992 & 6.1 & 6.7 & 7.6 & 13.4 & 3.9 & 19.1 & 56.8 \\
\hline 1993 & 12.3 & 13.0 & 17.8 & 13.4 & 10.9 & 19.4 & 86.8 \\
\hline 1994 & 16.2 & 1.5 & 10.2 & 6.0 & 9.8 & 7.0 & 50.7 \\
\hline 1995 & 17.7 & 22.0 & 15.2 & 7.3 & 8.2 & 4.8 & 75.2 \\
\hline 1996 & 14.8 & 14.2 & 9.0 & 13.1 & 1.4 & 14.8 & 67.3 \\
\hline 1997 & 9.5 & 14.9 & 14.5 & 5.8 & 7.5 & 4.0 & 56.2 \\
\hline 1998 & 15.3 & 6.5 & 19.3 & 10.3 & 11.8 & 2.5 & 65.7 \\
\hline 1999 & 10.3 & 6.8 & 16.8 & 10.0 & 2.3 & 1.5 & 47.7 \\
\hline 2000 & 6.2 & 15.8 & 15.1 & 6.8 & 3.8 & 8.3 & 56.0 \\
\hline 2001 & 6.0 & 8.4 & 9.3 & 15.9 & 9.8 & 9.3 & 58.7 \\
\hline 2002 & 19.0 & 24.7 & 3.1 & 5.1 & 7.2 & 18.8 & 77.9 \\
\hline 2003 & 12.4 & 32.2 & 11.9 & 4.0 & 13.5 & 12.6 & 86.6 \\
\hline 2004 & 6.5 & 13.5 & 5.4 & 8.1 & 4.8 & 0.0 & 38.3 \\
\hline 2005 & 10.0 & 4.7 & 6.5 & 10.8 & 18.2 & 6.8 & 57.0 \\
\hline 2006 & 7.5 & 10.2 & 7.0 & 21.3 & 7.7 & 21.3 & 75.0 \\
\hline 2007 & 8.2 & 7.3 & 7.1 & 9.9 & 4.5 & 7.4 & 44.4 \\
\hline 2008 & 11.6 & 6.6 & 5.8 & 11.6 & 7.0 & 3.2 & 45.8 \\
\hline 2009 & 12.9 & 20.0 & 9.9 & 34.7 & 9.4 & 13.2 & 99.9 \\
\hline 2010 & 8.8 & 12.2 & 10.5 & 6.8 & 9.2 & 8.5 & 55.2 \\
\hline 2011 & 35.3 & 21.4 & 20.6 & 11.1 & 7.8 & 16.6 & 112.6 \\
\hline 2012 & 3.3 & 1.6 & 3.0 & 9.4 & 6.7 & 13.2 & 37.1 \\
\hline 1989-2012 average & 11.0 & 12.1 & 9.8 & 9.8 & 7.9 & 9.5 & 59.8 \\
\hline 30-year average & 12.3 & 13.9 & 10.3 & 10.2 & 8.3 & 9.4 & 64.4 \\
\hline
\end{tabular}

water above the fragipan was extracted from all treatments including the NT system. In 1994, another year of low rainfall, the soybean yields were low for all treatments, but NT yield (Table 4) was substantially greater than CP and MP yields. In 1999, the NT corn yield of NT system was significantly greater than CP and MP. The 24-year average rainfall for the April through September period was $59.8 \mathrm{~cm}$ which is equal to the 30-year average (Table 2). Years of 1990, 1993, 1995, 2002, 2003, 2006, 2009, and 2011 were considered wet years.

From 1989 to 2012, tillage affected crop yields in only 1989, 1994, 1999, 2001, 2002, 2006, 2009, 2011, and 2012 (Table 4). In 1994,2002 , and 2012, the NT system produced significantly greater soybean yield than with the CP and MP systems partially due to greater plant population. Since 1994 and 2012 were dry years, and 2002 had a dry June to August period, the NT system could have provided more soil water to soybean at planting and later in the season compared with that of the other tillage systems. This enhanced soil water storage could have resulted in an improvement in nutrient availability and played an important role in greater soybean yields in 1994, 2002, and 2012 with the NT system as compared to MP and CP systems. Greater crop yield with the NT system than MP system in a dry year (not a drought) was also noted by Lueschen et al. [3]. Although the differences in soybean yield in 1996 were not significant by tillage treatment, the NT system had 8 and 16 percent greater yield than the MP and CP 
TABle 3: Effect of different tillage treatments on the corn and soybean populations during 1989-2012 at Dixon Springs.

\begin{tabular}{|c|c|c|c|c|c|c|c|}
\hline \multicolumn{8}{|c|}{ Plant population (1000 plants ha ${ }^{-1}$ ) } \\
\hline Corn year & 1989 & 1991 & 1993 & 1995 & 1997 & 1999 & \\
\hline NT & $55.3 \mathrm{~b}^{*}$ & $57.9 \mathrm{a}$ & $51.4 \mathrm{a}$ & $58.8 \mathrm{ab}$ & $46.9 \mathrm{a}$ & $69.2 \mathrm{a}$ & \\
\hline $\mathrm{CP}$ & $59.2 \mathrm{ab}$ & $47.4 \mathrm{~b}$ & 54.1a & $55.7 \mathrm{~b}$ & $51.9 \mathrm{a}$ & $64.2 \mathrm{ab}$ & \\
\hline MP & $62.9 \mathrm{a}$ & $52.2 \mathrm{ab}$ & $52.6 \mathrm{a}$ & $62.2 \mathrm{a}$ & $51.9 \mathrm{a}$ & $62.7 \mathrm{~b}$ & \\
\hline Year & 2001 & 2003 & 2005 & 2007 & 2009 & 2011 & 12-year average \\
\hline NT & $64.5 \mathrm{a}$ & $59.5 \mathrm{a}$ & $70.5 b$ & $68.8 \mathrm{a}$ & $65.0 \mathrm{a}$ & $75.7 \mathrm{a}$ & $59.4 \mathrm{a}$ \\
\hline $\mathrm{CP}$ & $56.5 \mathrm{~b}$ & $61.3 \mathrm{a}$ & $76.0 \mathrm{a}$ & $68.5 \mathrm{a}$ & $65.5 \mathrm{a}$ & $67.7 \mathrm{ab}$ & $58.6 \mathrm{a}$ \\
\hline MP & $65.9 \mathrm{a}$ & $60.0 \mathrm{a}$ & $69.5 \mathrm{~b}$ & $68.3 \mathrm{a}$ & $64.0 \mathrm{a}$ & $61.3 \mathrm{~b}$ & $60.2 \mathrm{a}$ \\
\hline Soybean year & 1990 & 1992 & 1994 & 1996 & 1998 & 2000 & \\
\hline NT & $191.0 b^{*}$ & $344.0 \mathrm{a}$ & $303.0 \mathrm{a}$ & $263.0 \mathrm{~b}$ & $271.0 \mathrm{~b}$ & $422.0 \mathrm{a}$ & \\
\hline $\mathrm{CP}$ & $247.0 \mathrm{a}$ & $335.0 \mathrm{a}$ & $229.0 \mathrm{~b}$ & $277.0 \mathrm{~b}$ & $273.0 \mathrm{~b}$ & $398.0 \mathrm{a}$ & \\
\hline MP & $249.0 \mathrm{a}$ & $343.0 \mathrm{a}$ & $181.0 \mathrm{c}$ & $309.0 \mathrm{a}$ & $294.0 \mathrm{a}$ & $405.0 \mathrm{a}$ & \\
\hline Year & 2002 & 2004 & 2006 & 2008 & 2010 & 2012 & 12-year average \\
\hline NT & $293.0 \mathrm{~b}$ & $240.0 \mathrm{a}$ & $320.0 \mathrm{a}$ & $310.0 \mathrm{~b}$ & $294.0 \mathrm{a}$ & $168.5 \mathrm{a}$ & $284.4 \mathrm{a}$ \\
\hline $\mathrm{CP}$ & $393.0 \mathrm{a}$ & $228.0 \mathrm{a}$ & $363.0 \mathrm{~b}$ & $390.0 \mathrm{a}$ & $279.0 \mathrm{a}$ & $125.6 \mathrm{~b}$ & $296.5 a$ \\
\hline MP & $420.0 \mathrm{a}$ & $255.0 \mathrm{a}$ & $388.0 \mathrm{c}$ & $360.0 \mathrm{ab}$ & $288.0 \mathrm{a}$ & $176.0 \mathrm{a}$ & $297.8 \mathrm{a}$ \\
\hline
\end{tabular}

${ }^{*}$ For each crop means in a same year followed by the same letter is not significantly different at the $P=0.05$ probability level.

TABLE 4: Effect of different tillage treatments on corn and soybean yields during 1989-2012 at Dixon Springs.

\begin{tabular}{|c|c|c|c|c|c|c|c|}
\hline \multirow{2}{*}{$\begin{array}{l}\text { Tillage } \\
\text { Corn year }\end{array}$} & \multicolumn{7}{|c|}{ Crop yield $\left(\mathrm{Mg} \mathrm{ha}^{-1}\right)$} \\
\hline & 1989 & 1991 & 1993 & 1995 & 1997 & 1999 & 2001 \\
\hline NT & $8.99 b^{*}$ & $6.57 \mathrm{a}$ & $11.79 a$ & $11.60 \mathrm{a}$ & $9.87 \mathrm{a}$ & $8.12 \mathrm{a}$ & $9.73 b$ \\
\hline $\mathrm{CP}$ & $9.99 b$ & $6.10 \mathrm{a}$ & $11.61 \mathrm{a}$ & $11.55 \mathrm{a}$ & $9.32 \mathrm{a}$ & $6.78 b$ & $9.60 \mathrm{~b}$ \\
\hline MP & $11.26 \mathrm{a}$ & $6.60 \mathrm{a}$ & $10.98 \mathrm{a}$ & $10.37 \mathrm{a}$ & $9.59 \mathrm{a}$ & $6.98 \mathrm{~b}$ & $10.34 \mathrm{a}$ \\
\hline Year & 2003 & 2005 & 2007 & 2009 & 2011 & 12-yr ave. & $\%$ of MP yield \\
\hline NT & $6.67 \mathrm{a}$ & $11.40 \mathrm{a}$ & $6.46 a$ & $13.10 \mathrm{a}$ & $6.13 a$ & $9.18 \mathrm{a}$ & 96 \\
\hline $\mathrm{CP}$ & $7.33 \mathrm{a}$ & $11.82 \mathrm{a}$ & $6.80 \mathrm{a}$ & $13.60 \mathrm{a}$ & $6.85 b$ & $9.24 \mathrm{a}$ & 97 \\
\hline MP & $7.82 \mathrm{a}$ & $11.41 \mathrm{a}$ & $7.33 \mathrm{a}$ & $14.03 \mathrm{~b}$ & $7.68 \mathrm{ab}$ & $9.53 \mathrm{a}$ & 100 \\
\hline Soybean year & 1990 & 1992 & 1994 & 1996 & 1998 & 2000 & 2002 \\
\hline NT & $2.37 \mathrm{a}$ & $3.74 \mathrm{a}$ & $2.87 \mathrm{a}$ & $2.63 a$ & $2.63 a$ & $2.32 \mathrm{a}$ & $2.37 \mathrm{a}$ \\
\hline $\mathrm{CP}$ & $2.62 \mathrm{a}$ & $3.46 \mathrm{a}$ & $1.81 \mathrm{~b}$ & $2.27 \mathrm{a}$ & $2.63 \mathrm{a}$ & $2.38 \mathrm{a}$ & $2.07 \mathrm{a}$ \\
\hline MP & $2.62 \mathrm{a}$ & $3.65 a$ & $1.49 \mathrm{~b}$ & $2.43 \mathrm{a}$ & $2.75 \mathrm{a}$ & $2.32 \mathrm{a}$ & $1.98 \mathrm{~b}$ \\
\hline Year & 2004 & 2006 & 2008 & 2010 & 2012 & 12 -yr ave. & $\%$ of NT yield \\
\hline NT & $0 \mathrm{a}$ & $3.17 \mathrm{ab}$ & $2.84 \mathrm{a}$ & $2.94 a$ & $2.65 a$ & $2.54 \mathrm{a}$ & 100 \\
\hline $\mathrm{CP}$ & $0 \mathrm{a}$ & $3.37 \mathrm{a}$ & $2.84 \mathrm{a}$ & $2.79 a$ & $1.96 \mathrm{~b}$ & $2.35 \mathrm{a}$ & 93 \\
\hline MP & $0 \mathrm{a}$ & $3.10 \mathrm{~b}$ & $3.04 \mathrm{a}$ & $2.88 \mathrm{a}$ & $1.82 \mathrm{~b}$ & $2.34 \mathrm{a}$ & 92 \\
\hline
\end{tabular}

${ }^{*}$ For each crop means in a same year followed by the same letter is not significantly different at the $P=0.05$ probability level.

systems, respectively. In 2002, the NT soybean yield (Table 4) was significantly greater than MP when the plant population (Table 3) was significantly less. Year 2002 was considered a wet year; however, the combination of a dry period (between June and August of 2002) and the greater number of plants in MP resulted in less water available per plant. In 2004, there were no measureable soybean yields on any of the tillage treatments. Growing season rainfall totaled $38.3 \mathrm{~cm}$ which is $26 \mathrm{~cm}$ below the average. In addition, the fall 2003 and winter and spring of 2004 had below average rainfall and the $15 \mathrm{~cm}$ water storage capacity of the Grantsburg moderately eroded soils was not full on April 1 which caused the soybean yield to be zero on all treatments.
A tillage study was conducted to determine the amount and rate of SOC storage and retention in NT and CP tillage system when compared to MP system as the comparison baseline. The SOC levels were determined at the end of the 24-year study (Table 5). The MP SOC level (43.1 $\mathrm{Mg} \mathrm{C} \mathrm{ha}^{-1}$ layer $^{-1}$ ) was significantly less for the $0-75 \mathrm{~cm}$ layer (root zone) than the NT (50.9 $\mathrm{Mg} \mathrm{C} \mathrm{ha}^{-1}$ layer $^{-1}$ ) and similar to the CP SOC value $\left(42.0 \mathrm{MgCha}^{-1}\right.$ layer $\left.^{-1}\right)$. The NT plots did store and retain more SOC in the soil $\left(7.8 \mathrm{Mg} \mathrm{Cha}^{-1}\right)$ and the CP plots less $\left(-1.6 \mathrm{MgC} \mathrm{ha}^{-1}\right)$ than MP. These SOC amounts were retained and stored in the soil and not decomposed and reemitted to the atmosphere as a 
TABLE 5: Paired comparisons using MP as baseline to determine no-till (NT) and chisel plow (CP) effects after 24 years of tillage treatments on the volumetric SOC content change of the Grantsburg soil.

\begin{tabular}{|c|c|c|c|c|}
\hline Tillage treatment & Depth cm & June 2012 & $\begin{array}{l}\text { Comparison method NT or CP versus } \\
\text { MP } 24 \text { yr total SOC retained above MP } \\
\qquad \mathrm{Mg} \mathrm{C} \mathrm{ha}^{-1} \text { layer }^{-1}\end{array}$ & $\begin{array}{l}\text { Paired comparison annual SOC retention } \\
\text { rate above MP the comparison baseline }\end{array}$ \\
\hline \multirow{3}{*}{ NT } & $0-15$ & $26.3 \mathrm{a}^{* *}$ & +7.5 & +0.31 \\
\hline & $15-75$ & $24.6 \mathrm{a}$ & +0.3 & +0.01 \\
\hline & 0-75 (all) & $50.9 \mathrm{a}$ & +7.8 & +0.32 \\
\hline \multirow{3}{*}{$\mathrm{CP}$} & $0-15$ & $20.3 b^{* *}$ & +1.5 & +0.06 \\
\hline & 15-75 & $21.7 \mathrm{a}$ & -2.6 & -0.11 \\
\hline & $0-75$ (all) & $42.0 \mathrm{~b}$ & -1.1 & -0.05 \\
\hline \multirow{3}{*}{ MP } & $0-15$ & $18.8 \mathrm{~b}$ & & \\
\hline & $15-75$ & $24.3 \mathrm{a}$ & & \\
\hline & $0-75$ (all) & $43.1 \mathrm{~b}$ & & \\
\hline
\end{tabular}

TABLE 6: Use of pretillage treatment 1988, 2000, and 2012 SOC during 24 years of tillage treatments.

\begin{tabular}{lcccc}
\hline $\begin{array}{l}\text { Tillage } \\
\text { treatment }\end{array}$ & Depth cm & $\begin{array}{c}\text { September 1988 } \\
\text { (pretreatment } \\
\text { baseline) }\end{array}$ & $\begin{array}{c}\text { August 2000 } \\
\mathrm{Mg} \mathrm{C} \mathrm{ha}^{-1} \text { layer }^{-1}\end{array}$ & June 2012 \\
\hline \multirow{2}{*}{ NT } & $0-15$ & $28.5 \mathrm{a}^{* *}$ & $26.8 \mathrm{a}^{* *}$ & $\begin{array}{c}26.3 \mathrm{a}^{* *} \\
\end{array}$ \\
& $15-75$ & $23.6 \mathrm{a}$ & $20.2 \mathrm{a}$ & $24.6 \mathrm{a}$ \\
& $0-75($ all) & $52.1 \mathrm{a}$ & $47.0 \mathrm{a}$ & $50.9 \mathrm{a}$ \\
\hline \multirow{2}{*}{ CP } & $0-15$ & $28.4 \mathrm{a}$ & $25.0 \mathrm{a}$ & $20.3 \mathrm{~b}$ \\
& $15-75$ & $23.5 \mathrm{a}$ & $18.7 \mathrm{ab}$ & $21.7 \mathrm{a}$ \\
& $0-75($ all $)$ & $51.9 \mathrm{a}$ & $43.7 \mathrm{ab}$ & $42.0 \mathrm{~b}$ \\
\multirow{4}{*}{ MP } & $0-15$ & $28.3 \mathrm{a}$ & $19.9 \mathrm{~b}$ & $18.9 \mathrm{~b}$ \\
& $15-75$ & $23.1 \mathrm{a}$ & $17.8 \mathrm{~b}$ & $24.3 \mathrm{a}$ \\
& $0-75($ all $)$ & $51.4 \mathrm{a}$ & $37.7 \mathrm{~b}$ & $43.1 \mathrm{~b}$ \\
\hline
\end{tabular}

${ }^{* *}$ Means six replications with the same letter and in the same year and depth with a different tillage treatment are not significantly different at $P=0.05$.

result of cultivation or in the transported sediment moved off of the plots.

Since the plot area was on 6\% slopes and eroding, the NT plot SOC storage and retention amount and rate benefited from a smaller soil erosion rate of $8 \mathrm{Mg} \mathrm{ha}^{-1} \mathrm{yr}^{-1}$ versus $20 \mathrm{Mg}^{-1} \mathrm{ha}^{-1} \mathrm{yr}^{-1}$ for $\mathrm{CP}$ and a soil erosion rate of $30 \mathrm{Mg}^{-1} \mathrm{ha}^{-1} \mathrm{yr}^{-1}$ for the MP plots (Table 1). The erosion rates were calculated using USLE and RUSLE2 [34, 35]. When MP loses SOC rich sediment from the plots and MP is the baseline, it has the effect of crediting NT (using comparison approach) with more SOC storage and retention.

Based on the paired comparison between NT and MP SOC in Table 5, it appears that NT stored and retained 7.8 (50.9-43.1) Mg C ha ${ }^{-1}$ more SOC than the MP plots at the end of the 24-year study. Using the comparison method [15, 2327] with SOC levels determined in the last year of the study and MP treatment as the baseline, the NT plots at Dixon Springs appear to have sequestered $7.8 \mathrm{MgCha}^{-1}$ of SOC in the soil. However, without knowing the SOC content in the plot area prior to or at the start of the tillage experiment (pretreatment SOC baseline), it would not have been possible to determine if SOC sequestration actually occurred and at the annual SOC retention rate $\left(0.32(7.8 / 24) \mathrm{MgC} \mathrm{ha}^{-1} \mathrm{yr}^{-1}\right)$ suggested in Table 5. These plots were sampled again and the SOC measured in August of 2000 and June of 2012 (Table 6) are lower than the initial September 1988 values for future NT, $\mathrm{CP}$ and MP plots sampled prior to tillage treatments being applied. The tillage plots (NT, CP and MP) lost SOC during the 24-year experiment and no SOC sequestration occurred on any of the tillage treatments. The NT plots actually lost a total of $-1.2 \mathrm{MgCha}^{-1}$, the CP lost $-9.9 \mathrm{MgCha}^{-1}$, and the MP lost $-8.2 \mathrm{Mg} \mathrm{Cha}^{-1}$ during the 24-year study (Table 7).

The annual loss in SOC in $\mathrm{MgCha}^{-1} \mathrm{yr}^{-1}$ is shown in Table 8. The NT rate of SOC loss from the root zone during the first 12 years was $-0.42 \mathrm{MgCha}^{-1} \mathrm{yr}^{-1}$ but gained SOC at the rate of $+0.33 \mathrm{MgCha}^{-1} \mathrm{yr}^{-1}$ during the last 12 years with an annual SOC loss rate for the 24 years of the tillage experiment was reduced to $-0.05 \mathrm{MgCha}^{-1} \mathrm{yr}^{-1}$. The CP rate of SOC loss from the root zone during the first 12 years was $-0.68 \mathrm{MgCha}^{-1} \mathrm{yr}^{-1}$ and the loss rate decreased to $-0.14 \mathrm{MgCha}^{-1} \mathrm{yr}^{-1}$ during the last 12 years with an annual SOC loss rate for the 24 years of the tillage experiment that was $-0.41 \mathrm{MgCha}^{-1} \mathrm{yr}^{-1}$. The MP rate of SOC loss from the root zone $(0-75 \mathrm{~cm})$ during the first 12 years was $-1.14 \mathrm{MgCha}^{-1} \mathrm{yr}^{-1}$ and gained $+0.45 \mathrm{MgCha}^{-1} \mathrm{yr}^{-1}$ during the last 12 years making MP annual loss rate $-0.34 \mathrm{MgCha}^{-1} \mathrm{yr}^{-1}$ for the entire 24-year tillage experiment (Table 8). The higher rate of SOC loss from all tillage treatments during the first 12 years would have been as a result of the land use conversion and cultivation of the 15year-old sod covered plot area.

\section{Discussion}

The 12-year average corn yield and the 12-year soybean yields were not affected by tillage (Table 4). Twelve-year average MP soybean yield was 2 and $9 \%$ greater than NT and CP 
TABLE 7: Use of pretillage treatment (1988) SOC values (sod) as baseline to determine the total SOC change in the first 12 years and during 24 years of tillage treatments. The 2000 SOC values for each plot were used as baseline to determine the total SOC content change during the last 12 years for the Grantsburg soil.

\begin{tabular}{|c|c|c|c|c|}
\hline Tillage treatment (6 replications) & Depth cm & $\begin{array}{c}\text { First 12-yr tillage effect on } \\
\text { SOC total change by } \\
\text { treatment using } 1988 \\
\text { baseline }\end{array}$ & $\begin{array}{c}\text { Last } 12 \text {-yr tillage effect on } \\
\text { SOC total change by } \\
\text { treatment using } 2000 \\
\text { baseline } \\
\mathrm{Mg} \mathrm{C} \mathrm{ha}^{-1} \text { layer }^{-1} \text { (\% change) }\end{array}$ & $\begin{array}{l}24 \text { year tillage effect on } \\
\text { SOC total change by } \\
\text { treatment using } 1988 \\
\text { baseline }\end{array}$ \\
\hline \multirow{3}{*}{ NT } & $0-15$ & $-1.7(-6)$ & $-0.5(-2)$ & $-2.2(-8)$ \\
\hline & $15-75$ & $-3.4(-14)$ & $+4.4(+22)$ & $+1.0(+4)$ \\
\hline & 0-75 (all) & $-5.1(-10)$ & $+3.9(+8)$ & $-1.2(-2)$ \\
\hline \multirow{3}{*}{$\mathrm{CP}$} & $0-15$ & $-3.4(-12)$ & $-4.7(-19)$ & $-8.1(-28)$ \\
\hline & $15-75$ & $-4.8(-20)$ & $+3.0(+16)$ & $-1.8(-8)$ \\
\hline & $0-75$ (all) & $-8.2(-16)$ & $-1.7(-4)$ & $-9.9(-19)$ \\
\hline \multirow{3}{*}{ MP } & $0-15$ & $-8.3(-29)$ & $-1.1(-5)$ & $-9.5(-34)$ \\
\hline & $15-75$ & $-5.3(-23)$ & $+6.5(+36)$ & $+1.2(+5)$ \\
\hline & 0-75 (all) & $-13.6(-27)$ & $+5.5(+14)$ & $-8.2(-16)$ \\
\hline
\end{tabular}

TABLE 8: Use of pretreatment SOC baseline (1988) to determine the rate of SOC change During the first 12 years and for 24 years of tillage. A 2000 baseline was used for the last 12 years on the volumetric SOC content $\left(\mathrm{Mg} \mathrm{C} \mathrm{ha}^{-1}\right.$ layer $\left.{ }^{-1} \mathrm{yr}^{-1}\right)$ of the Grantsburg soil.

\begin{tabular}{lcccc}
\hline Tillage treatment & Depth cm & $\begin{array}{c}\text { 1988 to 2000 tillage effect } \\
\text { on SOC rate of change by } \\
\text { treatment (baseline 1988) }\end{array}$ & $\begin{array}{c}\text { 2000 to 2012 tillage effect } \\
\text { on SOC rate of change by } \\
\text { treatment (baseline 2000) } \\
\text { Mg C ha } \text { layer }^{-1} \mathrm{yr}^{-1}\end{array}$ & $\begin{array}{c}\text { 24-year tillage effect on } \\
\text { SOC rate of change by } \\
\text { treatment (baseline 1988) }\end{array}$ \\
\hline NT & $0-15$ & -0.14 & -0.04 & -0.09 \\
& $15-75$ & -0.28 & +0.36 & +0.04 \\
\hline & $0-75$ (all) & -0.42 & +0.33 & -0.05 \\
CP & $0-15$ & -0.28 & -0.39 & -0.33 \\
& $15-75$ & -0.40 & -0.25 & -0.08 \\
MP & $0-75$ (all) & -0.68 & -0.14 & -0.41 \\
\hline
\end{tabular}

systems. The MP corn yields were $3 \%$ greater than for CP and NT systems as a result of significantly greater yields with MP system when planted into sod. At the beginning of the experiment, the MP system produced 21 and 11 percent higher yield compared with that of the NT and $\mathrm{CP}$ systems during 1989. The NT yields were lower in the early years of study but improved with the passage of time. The NT performance relative to MP and CP (Table 4) was better during dry years (1999) or years with extended dry period than wet years (Table 2), which was previously observed by Eckert [38]. The only year that CP treatment had the greatest yield was 2006 when compared to other tillage systems. The growing season rainfall that year was greater $(75 \mathrm{~cm})$ than average.

The NT crop yields were lower during the 3 early years (1989 to 1991) of the study but the NT system yielded as well as the MP system during the last 21 years of study. No-till yields were less than MP system in wet years (except 2002 with a dry period from June to August) but were greater in relatively dry years (Tables 2 and 4). The greater yields with the NT system in relatively dry years (1994, 1999, 2002, and 2012) were probably due to the conservation of more soil water than the MP system. Chisel plow yields were less in wet years and greater in dry years as compared to MP system (Table 4).

In the 1860 s, the plot area was under private ownership and was intensively cultivated until 1937 with some gully erosion evident in the 1937 air photographs. Land ownership changed from private to public at that time and plot area was then cultivated periodically until 1973 when it was in sod for 15 years. Clearly, the tillage effect on rate of SOC loss slowed or even started to gain over time (Table 6), but the NT, CP, and MP plots were still losing SOC (from pre-tillage treatment baseline) with no SOC being sequestered. Had the tillage experiment been established on a plot area which had been in row crops for the previous 15 years, it would appear that the rate of SOC loss to atmosphere and in transported sediment from MP, CP, and NT would have been reduced (Table 6). Tillage (NT and MP) treatments were starting to gain SOC in the last 12 years of the 24-year tillage study. In the NT, the 
SOC additions could be as a result of the annual additions of plant roots in topsoil and subsoil and crop residue being added on the soil surface. In the case of MP, the SOC annual additions included plant roots into the topsoil and subsoil and the incorporation of both roots and plant tops into the topsoil layer.

The SOC content of the MP (comparison baseline) did not appear to be at or reach a steady state during the 24year experiment since the SOC losses from water erosion, moldboard plow tillage, and mixing, some disturbance during planting and subsequent nitrogen injection in corn years and aeration was greater than any SOC sequestration or net SOC storage gain or mineralization gain in MP plots. Consequently, the SOC storage and retention reported in Table 5 for the NT system could not be verified as SOC sequestration using the pretreatment SOC values measured before during the 24-year tillage experiment and no SOC sequestration occurred on the NT plots. The same is true for the $\mathrm{CP}$ and MP plots.

If one were to compare the pretreatment SOC values for the NT, CP and MP (Table 8) with those measured at the end of the 24-years of a tillage experiment, one would find that SOC sequestration did not occur and that the NT lost $-0.05 \mathrm{MgC} \mathrm{ha}^{-1} \mathrm{yr}^{-1}$, the CP $-0.41 \mathrm{MgCha}^{-1} \mathrm{yr}^{-1}$, and the MP lost $-0.34 \mathrm{MgC} \mathrm{ha}^{-1} \mathrm{yr}^{-1}$. The NT SOC sequestration rate of $-0.05 \mathrm{MgC} \mathrm{ha}^{-1} \mathrm{yr}^{-1}$ (actually a SOC loss) is inconsistent with the central USA soil carbon sequestration rate of $0.40 \pm 0.61 \mathrm{MgCha}^{-1}$ year $^{-1}$ [23] and the southeast rate of $0.45 \pm 0.04 \mathrm{MgCha}^{-1}$ year $^{-1}$ [26] and inconsistent with a published national rate of $0.50 \mathrm{Mg}$ (or MT) $\mathrm{C} \mathrm{ha}^{-1}$ year $^{-1}$ [27]. No SOC sequestration occurred on the $24 \mathrm{yr}$ tillage study since the SOC levels of NT, CP, and MP were higher before the tillage treatment was applied than at the end of the study. The primary reason for SOC loss was the transport of carbon rich sediment from the plots by water erosion (responsible for 54 to $120 \%$ of the SOC storage loss in 24 years), moldboard plow or chisel plowing and mixing, some disturbance even on NT plots during planting and subsequent nitrogen injection in corn years, aeration, and mineralization.

Soil carbon sequestration (SOC) is the process of transferring carbon dioxide from the atmosphere into the soil through plants, plant residues, and other organic solids which are stored or retained as part of the soil organic matter (humus) [22]. The retention time of sequestered carbon in the soil can range from short-term (not immediately released back to atmosphere) to long-term (millennia) storage. The sequestered carbon process should increase the net soil organic carbon storage during and at the end of a study to above pretreatment baseline levels and result in a net reduction in the carbon dioxide levels in atmosphere. Olson [21] amended the definition of SOC sequestration to include meaningful boundaries to be used to measure actual changes in a specific part of a terrestrial (soil) pool. The proposed definition of soil organic carbon sequestration is the "process of transferring $\mathrm{CO}_{2}$ from the atmosphere into the soil of a land unit through unit plants, plant residues, and other organic solids, which are stored or retained in the unit as part of the soil organic matter (humus)".

Much of the literature [15, 23-27] suggested that paired comparisons between conservation tillage and conventional tillage at the end of a short- or long-term study can be used to determine SOC sequestration rate. Researchers assumed that the conservation and conventional tillage plots have the same SOC level at the start of the tillage experiment, the conventional tillage plots maintained the SOC over time (at steady state), and any increase in SOC of the conservation tillage treatment above the conventional tillage plot at end of study represented the amount of SOC sequestered by the conservation tillage system. However, these studies often lacked or did not report a pretreatment baseline SOC content in the plot areas collected prior to or at the start of the tillage experiment. Without such pretreatment baseline data, the SOC sequestration magnitude and rate findings cannot be verified [21].

If SOC sequestered in conservation tillage plots at the end of the experiment is higher than the initial SOC of the plot area then SOC sequestration would have occurred in the conservation tillage (NT) plots and at the measured rate. Alternatively, if the conservation tillage plots did not have more SOC content at the end of the study than at the start of the experiment (pretreatment baseline), then no SOC content sequestration occurred and the SOC sequestration rate is not correct. This long-term study was conducted on a plot area that was previously in sod for 15 years and on a 6 percent slope. The Grantsburg soils were previously eroded as a result of cropland use between 1860 and 1973. If the comparison approach is used, the projected SOC storage and retention (not sequestration) rate for NT would have been $0.32 \mathrm{MgC} \mathrm{ha}^{-1} \mathrm{yr}^{-1}$ (Table 5) which was less than the published regional SOC sequestration rate averages $(0.40 \pm$ $0.61 \mathrm{MgC} \mathrm{ha}^{-1} \mathrm{yr}^{-1}$ ) for the north central USA region [23]. Regional studies included both nearly level (flat) and sloping and eroding plot areas.

Since the SOC content in the Dixon Springs plot area was measured before the establishment of the tillage experiment (pretreatment baseline), it was possible to determine that the NT plots had lost $-1.2 \mathrm{MgCha}^{-1}$ (or 2\%) and the MP and CP plots had loss SOC $-8.3 \mathrm{MgCha}^{-1}$ (or 16\%) and $-9.9 \mathrm{MgCha}^{-1}$ (or 19\%), respectively over the 24 years. Contributing substantially to the above SOC losses from the tillage plots as a result of SOC rich sediment being transport off of the plots for the $24 \mathrm{yr}$ study was $2.4 \mathrm{Mg} \mathrm{Cha}^{-1}$ for NT, 5.3 $\mathrm{MgC} \mathrm{ha}^{-1}$ for $\mathrm{CP}$, and 7.2 $\mathrm{MgC} \mathrm{ha}^{-1}$ for MP. The NT plots did retain more SOC than MP plots; however, they did not sequester SOC. NT treatment only reduced the magnitude and rate of SOC loss over time. It is true that if a farmer had decided to use MP instead of NT the amount of SOC retained in the soil after 24-years of NT treatment would be $7.8 \mathrm{Mg} \mathrm{C}$ $\mathrm{ha}^{-1}$ greater than after 24 years of MP treatment and therefore the greenhouse gas emissions from the SOC in the NT plots would be less than from the SOC in the MP plots (but still greater than if the plot area had remained idle or in sod). 


\section{Conclusions}

Using the comparison method with MP as the baseline, the NT plots did store and retain $7.8 \mathrm{MgCha}^{-1}$ more SOC in the soil than MP and the $\mathrm{CP}$ stored and retain $-1.6 \mathrm{Mg} \mathrm{Cha}^{-1}$ less SOC in the soil than MP. That SOC amount was retained in the soil and not decomposed and reemitted to the atmosphere as a result of cultivation or in the transported sediment moved off of the plots. However, no SOC sequestration occurred in the NT, CP, and MP plots and SOC was actually lost since the SOC level of the plot area was greater at the start of the experiment than after 24 years of tillage treatments. At the end of the study the NT plots had $2 \%$ less SOC than the pretreatment plot area, CP had 19\% less SOC, and MP had $16 \%$ less SOC.

The comparison tillage study method with MP as baseline and with SOC measured in the last year of a $24 \mathrm{yr}$ study was used to determine the magnitude of SOC storage and retention rate for the conversion of MP tillage system to an NT or CP tillage system. However, the SOC storage and retention rates could not be validated as SOC sequestration since the pretreatment had significantly higher SOC in pretreatment plot area than in the NT, CP, and MP plots after a 24-year tillage study. The use of the tillage comparison method without establishing a pretreatment baseline (the SOC content of the plot areas prior to establishment of the tillage experiment) could in some cases, including this study, overestimate the amount of SOC sequestration, the SOC sequestration rate and underestimate the amount greenhouse gas released to the atmosphere from SOC during the study.

Findings suggest that a pretreatment SOC baseline was needed in this tillage comparison study to determine whether or not the NT and CP SOC storage and retention amount and rate findings actually resulted in SOC sequestration or loss. There was no SOC sequestration in the NT, CP, or MP plots since the SOC level of the plot area was greater at the start of the experiment than at the end of the $24 \mathrm{yr}$ study. Based on 24 years of crop yield measurements (12-year corn and 12-year soybean), the NT system appears to have resulted in similar long-term productivity compared with that of the MP and $\mathrm{CP}$ systems. The results of this study should be applicable to similar root-restricting, sloping, and moderately eroded soils in Illinois, Indiana, Missouri, and Kentucky.

\section{Funding}

This study is supported by NRES Research Project 65-372. It is also funded as part of Regional Research Project 367 and in cooperation with North Central Regional Project NC-1178 (Impacts of Crop Residue Removal on Soils).

\section{Acknowledgments}

This study is published with the approval of the Director of the Office of Research at the University of Illinois, Urbana, IL. NRES Research Project 65-372. It is funded as part of Regional Research Project 367 and in cooperation with North
Central Regional Project NC-1017 (Soil Carbon Sequestration).

\section{References}

[1] P. A. Lawrence, B. J. Radford, G. A. Thomas, D. P. Sinclair, and A. J. Key, "Effect of tillage practices on wheat performance in a semi-arid environment," Soil and Tillage Research, vol. 28, no. 3-4, pp. 347-364, 1994.

[2] W. W. Wilhelm, J. W. Doran, and J. F. Power, "Corn and soybean yield response to crop residue management under no tillage production system," Agronomy Journal, vol. 78, no. 1, pp. 184$189,1986$.

[3] W. E. Lueschen, S. D. Evans, J. H. Ford et al., "Soybean production as affected by tillage in a corn and soybean management system: I. Cultivar response," Journal of Production Agriculture, vol. 4, no. 4, pp. 571-579, 1991.

[4] G. Kapusta, R. F. Krausz, and J. L. Matthews, "Corn yield is equal in conventional, reduced, and no tillage after 20 years," Agronomy Journal, vol. 88, no. 5, pp. 812-817, 1996.

[5] E. C. Dickey, D. P. Shelton, P. J. Jasa, and T. R. Peterson, "Soil erosion from tillage systems used in soybean and corn residues," Transactions of the American Society of Agricultural Engineers, vol. 28, no. 4, pp. 1124-1129, 1985.

[6] E. E. Alberts and W. H. Neibling, "Influence of crop residue on water erosion," in Managing Agricultural Residues, P. W. Unger, Ed., vol. 13, pp. 19-44, Lewis, Boca Raton, Fla, USA, 1994.

[7] R. Lal, A. A. Mahboubi, and N. R. Fausey, "Long-term tillage and rotation effects on properties of a central Ohio soil," Soil Science Society of America Journal, vol. 58, no. 2, pp. 517-522, 1994.

[8] T. O. West and W. M. Post, "Soil organic carbon sequestration rates by tillage and crop rotation: a global data analysis," Soil Science Society of America Journal, vol. 66, no. 6, pp. 1930-1946, 2002.

[9] J. M. Baker, T. E. Ochsner, R. T. Venterea, and T. J. Griffis, "Tillage and soil carbon sequestration-what do we really know?” Agriculture, Ecosystems \& Environment, vol. 118, no. 1-4, pp. 1-5, 2007.

[10] A. J. VandenBygaart, E. G. Gregorich, and D. A. Angers, "Influence of agricultural management on soil organic carbon: a compendium and assessment of Canadian studies," Canadian Journal of Soil Science, vol. 83, no. 4, pp. 363-380, 2003.

[11] R. Lal, "Soil management and restoration for $\mathrm{C}$ sequestration to mitigate the accelerated greenhouse effect," Progress in Environmental Science, vol. 1, no. 4, pp. 307-326, 1999.

[12] R. A. Omonode, A. Gal, D. E. Stott, T. S. Abney, and T. J. Vyn, "Short-term versus continuous chisel and no-till effects on soil carbon and nitrogen," Soil Science Society of America Journal, vol. 70, no. 2, pp. 419-425, 2006.

[13] L. K. Mann, "Changes in soil carbon storage after cultivation," Soil Science, vol. 142, no. 5, pp. 279-288, 1986.

[14] G. E. Varvel and W. W. Wilhelm, "Long-term soil organic carbon as affected by tillage and cropping systems," Soil Science Society of America Journal, vol. 74, no. 3, pp. 915-921, 2010.

[15] A. J. Franzluebbers and R. F. Follett, "Greenhouse gas contributions and mitigation potential in agricultural regions of North America: introduction," Soil and Tillage Research, vol. 83, no. 1, pp. 1-8, 2005.

[16] I. Ismail, R. L. Blevins, and W. W. Frye, "Long-term no-tillage effects on soil properties and continuous corn yields," Soil 
Science Society of America Journal, vol. 58, no. 1, pp. 193-198, 1994.

[17] P. G. Hunt, D. L. Karlen, T. A. Matheny, and V. L. Quisenberry, "Changes in carbon content of a Norfolk loamy sand after 14 years of conservation or conventional tillage," Journal of Soil and Water Conservation, vol. 51, no. 3, pp. 255-258, 1996.

[18] D. A. Angers and M. Giroux, "Recently deposited organic matter in soil water-stable aggregates," Soil Science Society of America Journal, vol. 60, no. 5, pp. 1547-1551, 1996.

[19] R. L. Mulvaney, S. A. Khan, and T. R. Ellsworth, "Synthetic nitrogen fertilizers deplete soil nitrogen: a global dilemma for sustainable cereal production," Journal of Environmental Quality, vol. 38, no. 6, pp. 2295-2314, 2009.

[20] S. A. Khan, R. L. Mulvaney, T. R. Ellsworth, and C. W. Boast, "The myth of nitrogen fertilization for soil carbon sequestration," Journal of Environmental Quality, vol. 36, no. 6, pp. 18211832, 2007.

[21] K. R. Olson, "Soil organic carbon sequestration, storage, retention and loss in U.S. croplands: issues paper for protocol development," Geoderma, vol. 195-196, pp. 201-206, 2013.

[22] K. R. Olson, "Impacts of tillage, slope, and erosion on soil organic carbon retention," Soil Science, vol. 175, no. 11, pp. 562$567,2010$.

[23] J. M. F. Johnson, D. C. Reicosky, R. R. Allmaras, T. J. Sauer, R. T. Venterea, and C. J. Dell, "Greenhouse gas contributions and mitigation potential of agriculture in the central USA," Soil and Tillage Research, vol. 83, no. 1, pp. 73-94, 2005.

[24] M. A. Liebig, J. A. Morgan, J. D. Reeder, B. H. Ellert, H. T. Gollany, and G. E. Schuman, "Greenhouse gas contributions and mitigation potential of agricultural practices in northwestern USA and western Canada," Soil and Tillage Research, vol. 83, no. 1, pp. 25-52, 2005.

[25] A. J. Franzluebbers, "Soil organic carbon sequestration and greenhouse gas emissions in the southeastern United States," Soil Science Society of America Journal, vol. 74, no. 2, pp. 347357, 2005.

[26] A. J. Franzluebbers, "Achieving soil organic carbon sequestration with conservation agricultural systems in the southeastern United States," Soil Science Society of America Journal, vol. 74, no. 2, pp. 347-357, 2010.

[27] R. Lal, J. M. Kimble, R. F. Follett, and C. V. Cole, The Potential of U.S. Cropland To Sequesters Carbon and Mitigate the Greenhouse Effect, Sleeping Bear Press, Chelsea, Mich, USA, 1998.

[28] B. K. Kitur, K. R. Olson, S. A. Ebelhar, and D. G. Bullock, "Tillage effects on growth and yields of corn on Grantsburg soil," Journal of Soil and Water Conservation, vol. 49, no. 3, pp. 266271, 1994.

[29] K. R. Olson, S. A. Ebelhar, and J. M. Lang, "Impact of conservation tillage systems on maize and soybean yields of eroded Illinois soils," Journal of Agronomy, vol. 3, no. 1, pp. 3135, 2004.

[30] K. R. Olson, J. M. Lang, and S. A. Ebelhar, "Soil organic carbon changes after 12 years of no-tillage and tillage of Grantsburg soils in southern Illinois," Soil and Tillage Research, vol. 81, no. 2, pp. 217-225, 2005.

[31] Soil Survey Staff, "Soil taxonomy, a basic system of soil classification for making and interpreting soil survey," in United States Department of Agriculture Handbook 436, p. 869, Government Printing Office, Washington, DC, USA, 2nd edition, 1999.

[32] W. G. Cochran and G. M. Cox, Experimental Design, vol. 13, John Wiley and Sons, New York, NY, USA, 2nd edition, 1957.
[33] P. R. Hill, J. V. Manning, and J. R. Wilcox, Estimating Corn and Soybean Residue Cover, Agronomy Guide. Purdue University Cooperative Extension Service, West Lafayette, Ind, USA, 1989.

[34] N. Widman, RUSLE2-Instructions and User Guide, USDA, Natural Resources Conservation Service, Washington, DC, USA, 2004.

[35] R. D. Walker and R. A. Pope, Estimating Your Soil Erosion Losses With the Universal Soil Loss Equation (USLE), University of Illinois, Extension Service Circular, 1983.

[36] Soil Survey Staff, “Soil survey laboratory methods manual," Soil Survey Investigations Report, 42, Version 4. 0, National Soil Survey Center, Lincoln, Mass, USA, 2004.

[37] S. A. S. Institute, SAS/STAT Guide For Personal Computers Version 6, SAS Institute, Cary, NC, USA, 2002.

[38] D. J. Eckert, "Tillage system planting date interactions in corn production," Agronomy Journal, vol. 76, no. 4, pp. 580-582, 1984. 

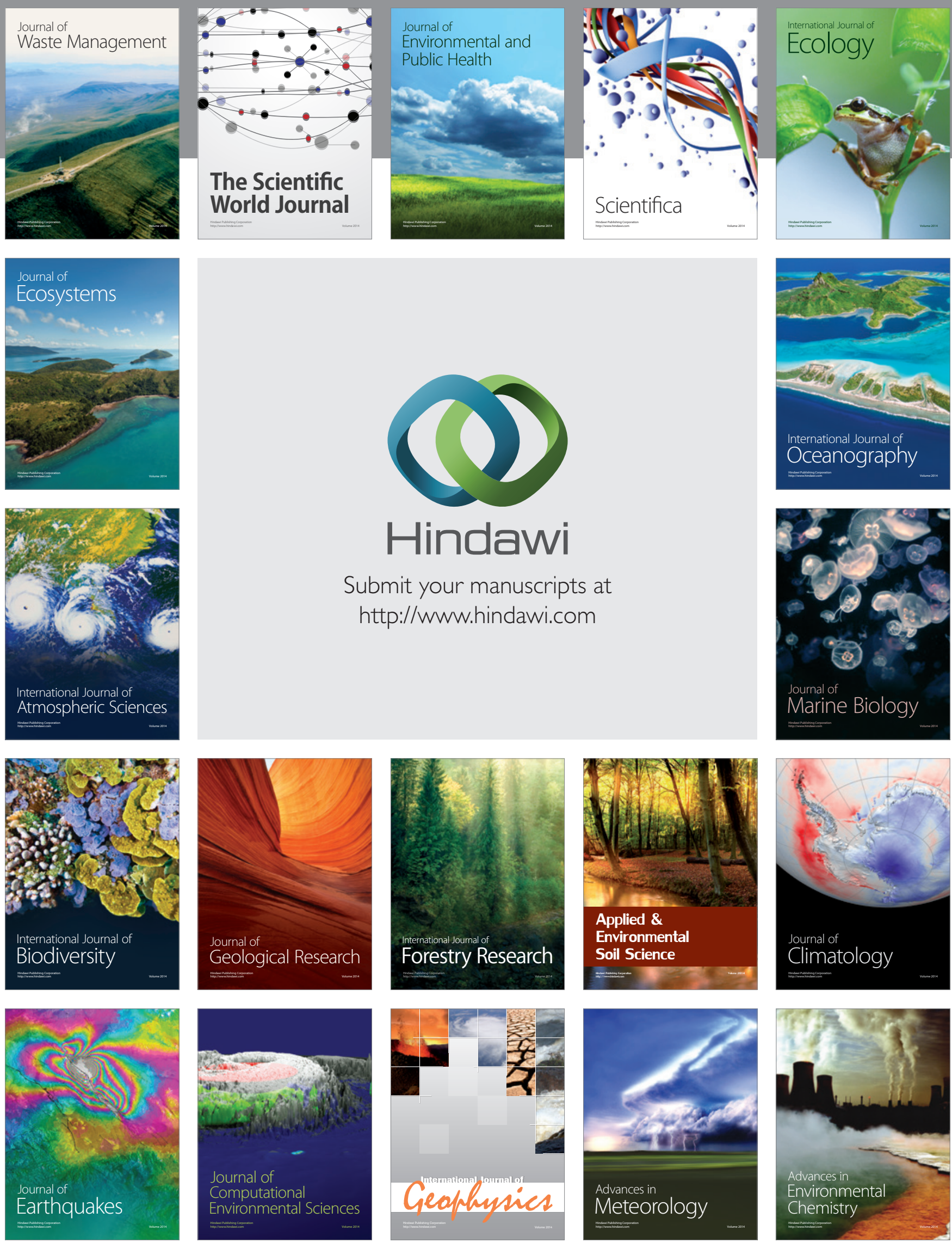